\title{
PROTECTIVE EFFECT OF CHLORELLA VULGARIS ON DNA DAMAGE, OXIDATIVE STRESS, AND LUNG MORPHOLOGICAL CHANGES IN CIGARETTE SMOKE-EXPOSED RATS
}

\author{
ZAMRI KS ${ }^{1}$, NORRIPIN MKN ${ }^{1}$, DARUS FI ${ }^{1}$, EKAMBARAM DG ${ }^{1}$, ABDUL RAOF ND $^{1}$, ROSLAN NH ${ }^{1}$, AHMAD F $^{2}$, \\ MOHAMMED $F^{3}$, MAKPOL $S^{1}$, MOHD YUSOF YA ${ }^{1 *}$
}

${ }^{1}$ Department of Biochemistry, Faculty of Medicine, Universiti Kebangsaan Malaysia Medical Centre, Kuala Lumpur, Malaysia. ${ }^{2}$ Department of Anatomy, Faculty of Medicine, Universiti Kebangsaan Malaysia Medical Centre, Kuala Lumpur, Malaysia. ${ }^{3}$ Department of Pathology, Faculty of Medicine, Universiti Kebangsaan Malaysia Medical Centre, Kuala Lumpur, Malaysia. Email: rahmatyasmin@yahoo.com

Received: 31 Mach 2018, Revised and Accepted: 11 June 2018

\begin{abstract}
Objective: The aim of this study was to determine the protective effect of Chlorella vulgaris (ChV), antioxidant-rich unicellular green alga, and in cigarette smoke-exposed rats.

Methods: Male Sprague Dawley rats were divided into 4 groups: Control Group (C), ChV group (300 mg/kg body weight), cigarette smoke-exposed (S) group, and S group treated with $\mathrm{ChV}(\mathrm{S}+\mathrm{ChV})$. Blood samples were drawn from the orbital sinus on days 0,15 , and 30 for the determination of DNA damage by Comet assay and plasma malondialdehyde (MDA) using high-performance liquid chromatography. Rats were killed on day 30 , and lung tissue samples were taken for the evaluation of airspace enlargement and number of inflammatory cells.
\end{abstract}

Results: Increased DNA damage (1004.8 au + 329.2, day 15; $1102.7+197.8$, day 30) and high MDA levels (10.66 + 0.27, day $15 ; 10.29+0.9$ day 30) were found in cigarette smoke-exposed rats on days 15 and 30 but were reduced significantly (p<0.05) when treated with ChV (DNA: $482.6+223.3$, day15; $423.5+74.6$, day 30 and MDA: $6.1+0.6$, day15; $6.6+2.5$, day 30 ) for both days. Hematoxylin and eosin staining showed that cigarette smokeexposed rats had high frequency of airspace enlargement and number of inflammatory cells which were reduced when treated with ChV.

Conclusion: $\mathrm{ChV}$ has a protective role in cigarette smoke-exposed rats by reducing oxidative DNA damage, MDA levels, lung cells inflammation, and airspace enlargement.

Keywords: Chlorella vulgaris, DNA damage, Malondialdehyde, Inflammatory cells, Airspace enlargement.

(C) 2018 The Authors. Published by Innovare Academic Sciences Pvt Ltd. This is an open access article under the CC BY license (http://creativecommons. org/licenses/by/4. 0/) DOI: http://dx.doi.org/10.22159/ajpcr.2018.v11i10.26352

\section{INTRODUCTION}

Cigarette smoke consists of a complex and reactive mixture of harmful chemicals. Majority of these chemicals are hazardous to health and can cause chronic inflammatory lung diseases including chronic obstructive pulmonary disease (COPD) and respiratory related diseases including lung cancer [1]. The generation and accumulation of free radicals as a result of smoking and the imbalance between oxidants and antioxidants in our body may play a central role in the pathogenesis of smokinginduced airways diseases such as COPD and emphysema [2,3]. Cigarette smoke was shown to induce oxidative stress and apoptosis in human lung fibroblasts [4]. Polycyclic aromatic hydrocarbons, a carcinogenic agent found in cigarette smoke, intercalate between bases in DNA causing damage and initiate the carcinogenic process in lung cells [5]. Smoking was also found to increase the number of the goblet and inflammatory cells within the epithelium of peripheral airways causing chronic bronchitis and airflow limitation [6]. In addition, smoking can also cause airspace enlargement in a smoke-induced rat model [7]. Airspace enlargement is one of the pathogenesis of emphysema in COPD due to chronic lung inflammation that caused an imbalance between proteases and anti-proteases causing disruption of extracellular matrix, enhanced apoptosis and loss of alveolar units [8]

Alternative medicines have been the focus of recent research in ameliorating complications caused by cigarette smoking. Administration of Chinese green tea followed by cigarette smoke exposure ameliorated lung injury which was associated with decreased oxidative stress marker serum 8-isoprostane level, and an increase in lung antioxidant enzymes [9]. Banerjee et al. [10] have shown that cigarette smoke exposure to guinea pigs resulted in progressive protein damage, inflammation, apoptosis, and lung injury. However, administration of Vitamin C (15 mg of Vitamin C/guinea pig/day) prevented the pathophysiological changes significantly. Koike et al. [11] showed that Vitamin C treatment on SMP30-KO mice after cessation of cigarette smoke exposure prevents emphysema as indicated by the pulmonary restoration. In addition, Vitamin $\mathrm{C}$ diminished oxidative stress, increased collagen synthesis, and improved vascular endothelial growth factor levels in the lungs. Tualang honey supplementation to smokers reduced plasma F2-isoprostane and increased total antioxidant status level as well as glutathione peroxidase and catalase activity, suggesting that honey reduced oxidative stress in smokers [12]. Broccoli intake was associated with increased protection against $\mathrm{H}_{2} \mathrm{O}_{2}$-induced DNA strand breaks and lower levels of oxidized DNA bases in peripheral blood mononuclear cells from smokers [13]. Muda et al. [14] have demonstrated that honey supplementation to cigarette smoke-induced rats reduced the number of macrophages in the interalveolar septa of lungs compared to smoke-induced rats. Carob aqueous extract given to rats exposed to water pipe smoke for 8 weeks showed protective effects in the liver and kidney functions as well as decreased malondialdehyde (MDA) and glutathione levels [15]. Nithya et al. [16] demonstrated that thymoquinone restored the damage caused by benzo[a]pyrene (found in cigarette smoke) in lung cancer induced Swiss albino mice.

Chlorella vulgaris (ChV) is a unicellular microalga which contains a wide variety of antioxidant compounds including beta-carotene, chlorophyll, alfa-tocopherol, ascorbic acid, lycopene, lutein, zeaxanthin, Vitamin C, and Vitamin E $[17,18]$. In streptozocin-induced diabetic rats, ChV was shown to reduce oxidative stress [19]. Patients with obstructive pulmonary disorders supplemented with $2.7 \mathrm{~g} /$ day of $\mathrm{ChV}$ had a low frequency of coughing, shortness of breath, wheezing, and coughed-out sputum. [20] 
Since smoking is associated with chronic inflammatory lung disease as a result of harmful free radical species found cigarette smoke, our study was thus conducted with the aim of evaluating the possible protective effect of $\mathrm{ChV}$ in cigarette smoke-induced rats by determining DNA damage, lung morphological changes, and oxidative stress marker, MDA.

\section{METHODS}

\section{Animal experimental design}

The experimental design was approved by Universiti Kebangsaan Malaysia (UKM) Animal Ethics Committee (UKMAEC: BIOK/PP/2017/YASMIN/29MARCH/832-MAY-2017-MAY-2018). The experiments were conducted according to the guidelines of UKMAEC at IVC Lab, 8 floor, Preclinical Building, UKM Medical Centre (UKMMC), Cheras, Kuala Lumpur.

A total of 28 male Sprague Dawley rats aged between 7 and 9 weeks weighed from $200 \mathrm{~g}$ to $250 \mathrm{~g}$ were obtained from Laboratory Animal Resource Unit, Faculty of Medicine, UKM. The rats were acclimatized before the experiment and were kept in IVC cages in a room with controlled temperature and humidity with $12 \mathrm{~h}$ light/12 h dark cycle, and fed with standard commercial rat pellet and drinking water.

The rats were randomly divided into four groups, control Group (C): Rats fed with standard commercial rat pellet (Animal Lab, UKM); S group: Rats fed with standard commercial rat pellet and exposed to cigarette smoke; ChV: Rats fed with standard commercial pellet plus $300 \mathrm{mg} / \mathrm{kg}$ body weight ChV; and S+ChV: Smoke-exposed (S) group fed with $300 \mathrm{mg} / \mathrm{kg}$ body weight $\mathrm{ChV}$. For each smoke exposure, the smoke produced from 10 burning cigarettes in one compartment was continuously ventilated by 2 air pumps to another compartment where the rats were placed. They were exposed to the smoke for 30 min daily for 30 days. The smoke chamber was based on the work by Cesar-Neto et al. [21]. The ChV dose of $300 \mathrm{mg} / \mathrm{kg}$ body weight was chosen based on our previous experiment evaluating the antitumor effect of $\mathrm{ChV}$ in hepatocarcinogenesis-induced rats [22]. ChV of $300 \mathrm{mg} / \mathrm{kg}$ body weight was diluted with $1 \mathrm{ml}$ of distilled water and administered by oral gavage (27-gauge stainless steel feeding needle) to rats daily after 1 -h post-cigarette smoke exposure for 30 days.

\section{Sample preparation}

The duration of the experiment was 30 days, and the blood sample of $5 \mathrm{ml}$ from each rat was collected through orbital sinus at days 0,15 , and 30. An amount of $1 \mathrm{ml}$ fresh whole blood was used for Comet assay, and the rest were centrifuged at $3000 \mathrm{rpm}, 4^{\circ} \mathrm{C}$ for $10 \mathrm{~min}$, and the plasma obtained was divided into aliquots and stored at $-80^{\circ} \mathrm{C}$ for MDA determination. All rats were euthanized by the end of day 30 . The lungs were removed and fixed in $10 \%$ formalin solution for $48 \mathrm{~h}$. The tissues were processed in an automatic tissue processor (Leica/ Thermo Shandon, UK) for $15 \mathrm{~h}$, and embedded with paraffin wax into tissue blocks. The blocks were serially sectioned at $3 \mu \mathrm{m}$ thickness from base to apex using a microtome (Leica/Reichert Jung, USA). Four random sections from each tissue block were selected for hematoxylin and eosin ( $\mathrm{H}$ and $\mathrm{E}$ ) staining and morphological evaluation: Airspace enlargement and inflammatory cells [14].

\section{ChV extract}

The stock of $\mathrm{ChV}$ Beijerinck (strain 072) was obtained from the Department of Biochemistry, UKMMC, Cheras, Kuala Lumpur. ChV was cultured indoor in a $5 \mathrm{~L}$ conical flask in Bold Basal Media with $24 \mathrm{~h}$ light and sufficient aeration. The algae were centrifuged $3 \times$ at $3000 \mathrm{rpm}$ for $10 \mathrm{~min}$ at $40^{\circ} \mathrm{C}$ to separate the media. The pelleted algae were diluted in $1 \mathrm{ml}$ of distilled water at $300 \mathrm{mg} / \mathrm{kg}$ body weight before being used throughout the experiment [19].

\section{DNA damage by COMET assay}

The comet assay was carried out based on the methods by Singh et al. [23] with slight modifications. Fully frosted microscope slides were covered with $80 \mu \mathrm{l} 0.6 \%$ normal melting point agarose (Sigma-Aldrich, St Louise, MO, USA) at $60^{\circ} \mathrm{C}$. The slides were placed on an ice-cold flat tray to allow the agarose to solidify. An amount of $5 \mu \mathrm{l}$ of whole fresh blood was mixed with $70 \mu \mathrm{l}$ of $0.6 \%$ low melting point agarose (at $37^{\circ} \mathrm{C}$ ) and spread on the slides. The slides were immersed into cold lysing solution $(2.5 \mathrm{M} \mathrm{NaCl}, 100 \mathrm{mM}$ ethylene-diamine tetra-acetic acid, $10 \mathrm{mM}$ Tris at $\mathrm{pH} 10,1 \%$ Triton $\mathrm{X}-100,1 \%$ sodium N-lauroyl sarcosinate, and $10 \%$ dimethyl sulfoxide) at $4^{\circ} \mathrm{C}$ for $1 \mathrm{~h}$. The slides were then placed in an alkaline electrophoresis buffer for $20 \mathrm{~min}$ to allow the unwinding of DNA. The electrophoresis was conducted at $25 \mathrm{~V}$ with the current adjusted to $300 \mathrm{~mA}$. Following electrophoresis, the slides were rinsed with buffer then drained and stained with $30 \mu \mathrm{l}$ ethidium bromide and were examined at $200 \times$ magnification using a fluorescent microscope (Olympus Corp., Shibuya-ku, Tokyo, Japan).

DNA damage score is an arbitrary scale of $0-4$ with score $0=$ no damage; score 1-2 = mild damage; score 3-4 = severe damage. For final analysis, total damage score of each slide was calculated using the following formula: Arbitrary unit = score $0(n)+$ score $1(n)+$ score $2(n)+$ score $3(n)+$ score $4(n) ; n=$ the number of cells.

\section{Determination of plasma MDA level}

MDA, a lipid peroxidation product, was quantified using the method of Mateos et al. [24]. This assay was based on the principle of MDA derivation with 2,4-dinitrophenylhydrazine (DNPH), which is then converted into its derivatives, pyrazole, and hydrazone, and is separated using ultra high-performance liquid chromatography (HPLC). HPLC analyses were performed on an LC-10 AT VP SHIMADZU (Kyoto, Japan). A Shimadzu Class-VP software system was used for data processing. Briefly, $50 \mu \mathrm{l}$ samples were mixed with $200 \mu \mathrm{L} 1.3 \mathrm{M} \mathrm{NaOH}$ and incubated at $60^{\circ} \mathrm{C}$ for $60 \mathrm{~min}$. After cooling the mixture, $100 \mu \mathrm{L}$ of $35 \% \mathrm{HCIO}_{4}$ was added and centrifuged at $10,000 \mathrm{~g}$ for $10 \mathrm{~min}$ at $4^{\circ} \mathrm{C}$. The supernatant of the samples $(300 \mu \mathrm{L})$ was transferred into $1.5 \mathrm{ml}$ HPLC tube. An amount of $50 \mu \mathrm{l}$ of $5 \mathrm{mM}$ DNPH solution was added to the mixture and incubated for $30 \mathrm{~min}$ at room temperature. Then, $40 \mu \mathrm{L}$ samples were injected into the HPLC and detected at $310 \mathrm{~nm}$.

\section{Histopathological evaluation}

\section{Microscopic assessment}

Each section of the lung was examined by an experienced pathologist using a light microscope and an image analyzer using the (Olympus cellSens Standard software, v1.14). The prominent pathological changes were summarized for each rat

\section{Airspace enlargement}

The presence of airspace enlargement is defined by abnormal, permanent enlargement of airspace distal to the terminal bronchiole accompanied by destruction of their walls with or without fibrosis [8]. The sections were classified into "present" and "absent."

\section{Inflammatory cells}

The degree of inflammation was evaluated on a scale from 0 to 3 by a pathologist. The scale was defined as follows: $0=$ no inflammation, 1 = mild inflammation, 2 = moderate inflammation, and $3=$ severe inflammation. Normal inflammation is defined by the presence of inflammatory cells within the normal limit, mild inflammation is defined by occasional foci of chronic inflammatory cells within interstitium, moderate inflammation is defined by mild and focally increased chronic inflammatory cells within airway (smooth muscle), and severe inflammation is defined by diffused infiltration of chronic inflammatory cells within airway and interstitium.

\section{Statistical analyses}

All data were analyzed using Statistical Package for the Social Sciences (SPSS) software version 22.0 at the significant level $\mathrm{p}<0.05$.

\section{RESULTS AND DISCUSSION}

\section{DNA damage and effects of ChV}

Cigarette smoke is known to have numerous toxic chemicals that are harmful to human health by inducing oxidative damage to many tissues especially the lung. Hydroxyl radicals generated by aqueous cigarette tar were shown to cause oxidative DNA damage in smokers [25]. There was 
a significant increase in DNA damage in the smoke-exposed group(S) on day 15 and day 30 when compared to the control group, respectively $(\mathrm{p}<0.05)$ (Fig. 1). The increase in DNA damage can be explained by the depletion of antioxidants such as glutathione, superoxide dismutase (SOD), and catalase caused by the free radical reactive species found in cigarette smoke [26]. Interestingly when the cigarette-smoke exposed rats were treated with the microalgae $\mathrm{ChV}$, it reduced DNA damage significantly $(p<0.05)$ when compared to the control group and $S$ group for both days (15 and 30). This finding proves that $\mathrm{ChV}$ has a protective effect toward oxidative DNA damage which is most likely due to its antioxidant properties [19]. Similarly, other research studies have also shown the beneficial and protective effects of some antioxidants in cigarette smoke-exposed rodents. Koike et al. [11] showed that Vitamin C prevents cigarette smoke-induced pulmonary emphysema in mice and provides pulmonary restoration as well as reduced ROS level. Chan et al. [9] showed that Chinese green tea ameliorates lung injury in cigarette smoke-exposed rats; while Mohamed et al. [27] showed that honey exhibits an antioxidant protective effect in cigarette smoke-induced testicular damage in rats. Luchese et al. [26] showed that antioxidant diphenyl diselenide, an organoselenium compound, restored antioxidant defense in lungs and brain tissues of rats.

\section{Oxidative stress marker MDA and effects of $\mathrm{ChV}$}

There were no significant changes in MDA levels within the $S$ group on days 15 and 30 when compared with the control group ( $>0.05$ ) (Fig. 2). However, $\mathrm{ChV}$ alone managed to reduce the baseline MDA levels in the control group significantly $(\mathrm{p}<0.05)$ on day 15 but not day $30(\mathrm{p}>0.05)$. Interestingly, when the $\mathrm{S}$ group was treated with $\mathrm{ChV}(\mathrm{S}+\mathrm{ChV}), \mathrm{MDA}$ levels for both days reduced significantly $(\mathrm{p}<0.05)$. Our previous finding has shown that $\mathrm{ChV}$ has a protective effect against oxidative damage in rats induced with liver cancer by reducing elevated MDA levels [22]. In a study to determine the effect of antioxidant $\mathrm{N}$-acetyl cysteine (NAC) in rats induced with myocardial infarct by cigarette smoke, Khanna et al. [28] found that NAC resulted in significantly increased levels of cardiac mRNA expression of antioxidants, including SOD, thioredoxin, and nuclear factor-E2-related factor 2, as well as circulating levels of glutathione where the levels were almost identical to the tobacconaïve sham rats. Chan et al. [9] showed that epigallocatechin-3-gallate (EGCG) in green tea managed to reduce the elevated levels of serum 8-isoprostane, lung SOD, and catalase activities in cigarette smokeexposed rats compared to sham air-exposed rats.

Effects of $\mathrm{ChV}$ on inflammation of lung tissues determined by histological changes

Smoking induced inflammatory reaction in the airways and lung parenchyma which comprised of neutrophils, alveolar macrophages, and $\mathrm{T}$ lymphocytes [29]. The macrophages release various compounds such as proteinase, reactive oxygen species, chemotactic factors, and inflammatory cytokines, which could cause direct injury to the cells within the airways and enhance further inflammatory reactions [30,31]. In this study, we found an increase in inflammatory cells within the interalveolar septa of $S$ group when compared with the control group $(\mathrm{p}<0.05)$ on day 30 . Interestingly, $\mathrm{ChV}$ reverse the effect by reducing the number of inflammatory cells significantly $(\mathrm{p}<0.05)$ (Fig. 3). Representative histological observations for inflammatory cells are shown in Fig. 4. Thus, it shows that the administration of $\mathrm{ChV}$ improved the severity of inflammation perhaps by the action of its antioxidant and anti-inflammatory properties [32]. The properties of antioxidant and anti-inflammatory in herbs and seaweeds have been shown by other researchers to be due to the presence of active metabolites such as phenols and other phytochemicals [33,34]. Al-Waida et al. [35] similarly showed improvement of inflammation involving lymphocytes and plasma cells of lungs when the cigarette smoke-exposed rats were supplemented with Chinese green tea (EGCG).

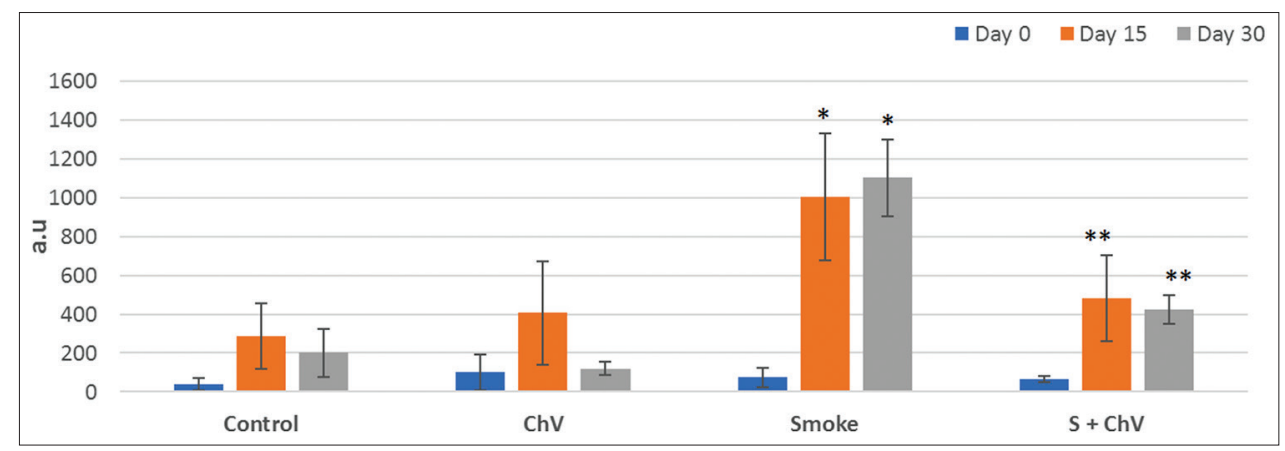

Fig. 1: Effect of Chlorella vulgaris on total DNA damage score in cigarette smoke-exposed rats. Data are expressed as mean \pm standard deviation. *Significantly different $(p \leq 0.05)$ compared to the control group at the same day and ${ }^{* *}$ significantly different $(p \leq 0.05)$ compared to the smoke group at the same day

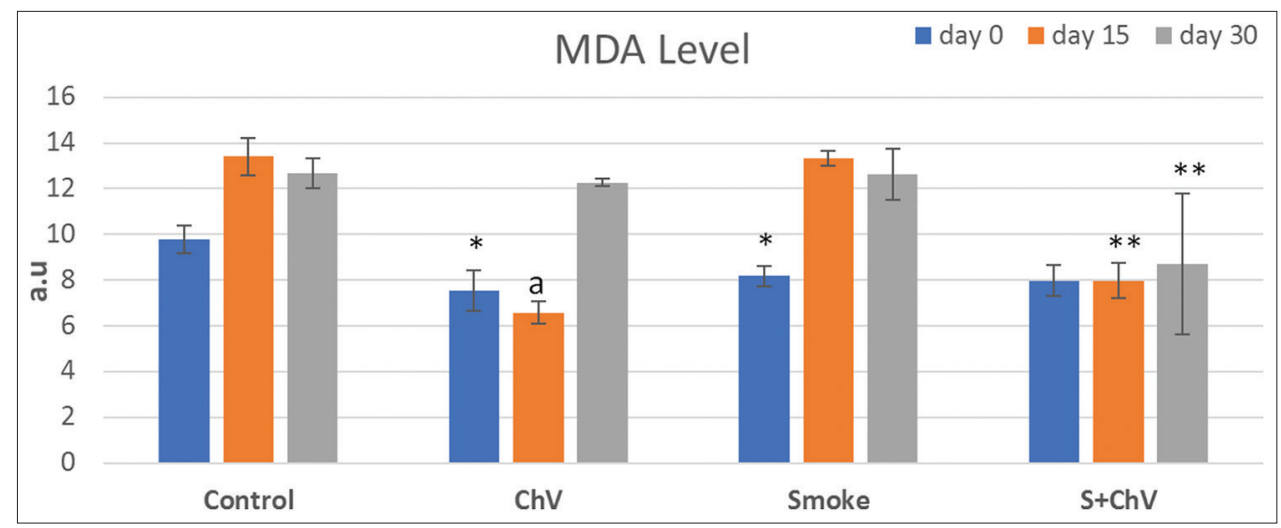

Fig. 2: Blood malondialdehyde level in cigarette smoke-exposed rats with or without Chlorella vulgaris treatment. Data are expressed as means \pm standard deviation. *Significantly different $(\mathrm{p} \leq 0.05)$ compared to control group at the same day and $* *$ significantly different $(p \leq 0.05)$ compared to $S$ group at the same day 


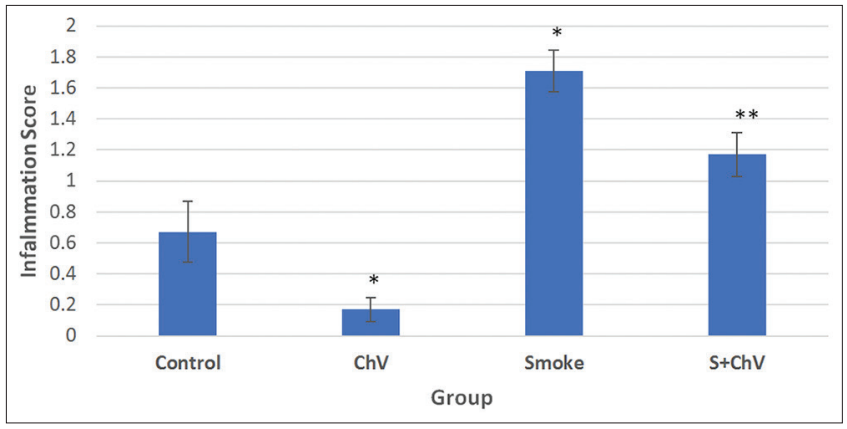

Fig. 3: Inflammation score in cigarette smoke-exposed rats (S) with or without Chlorella vulgaris treatment. Lung tissues were collected and fixed in paraffin wax on day 30 when the rats were sacrificed. Data are expressed mean \pm standard error of the mean

*Significantly different ( $p \leq 0.05)$ compared to control group;

**significantly different $(\mathrm{p} \leq 0.05)$ compared to $S$ group

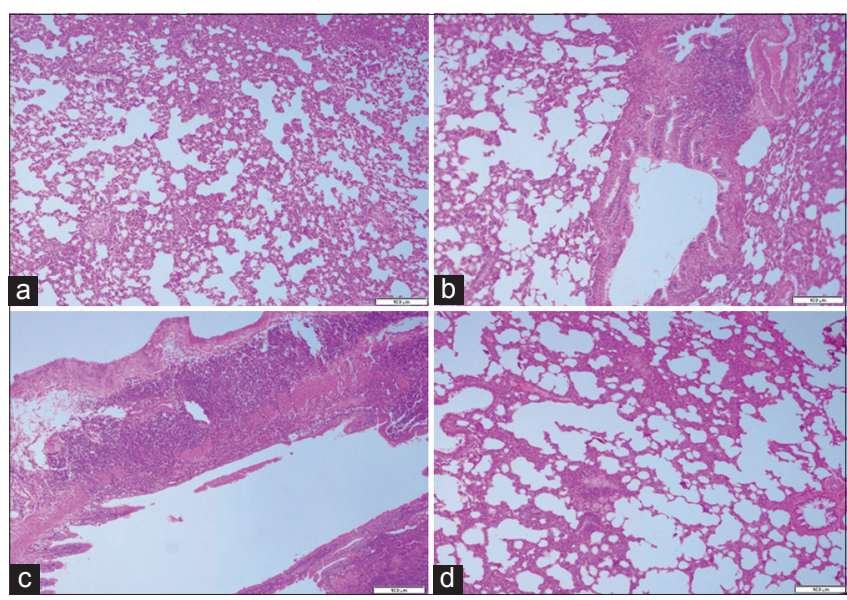

Fig. 4: Photomicrographs of lung sections showing the effect of Chlorella vulgaris $(\mathrm{ChV})$ on the number of inflammatory lung cells in the cigarette smoke-exposed (S) rats. Control group (a), $\mathrm{ChV}$ group (b), $\mathrm{S}$ group (c), and $\mathrm{S}+\mathrm{ChV}$ group (d). The severity of inflammation of is indicated by a: Normal, b: Mild, c: Severe, and d: Moderate. Scale bar $100 \mu \mathrm{m}$. $\mathrm{H}$ and $\mathrm{E}$ photomicrographs are under $100 \times$ magnification

Effects of $\mathrm{ChV}$ on airspace enlargement determined by histological changes

Long-term cigarette smoking predisposes individuals to COPD [36]. Guinea pigs and mice are perhaps the most susceptible species, developing significant airspace enlargement within a few months of cigarette smoke exposure $[8,36]$. Table 1 summarized the frequency of rats with airspace enlargement in $\mathrm{S}$ and $\mathrm{S}+\mathrm{ChV}$ groups while (Fig. 5) represents the histopathological examination and observations. All rats $(\mathrm{n}=6)$ in control (Fig. 5a) and $\mathrm{ChV}$ groups showed similar histological findings having normal airspace enlargement, but smoking-induced obvious airspace enlargement in all rats in the $S$ group (Fig. 5c). Treatment with $\mathrm{ChV}$ interestingly reduced the frequency of rats with airspace enlargement (4/6) (Fig. 5d). This could be due to the anti-inflammatory property of $\mathrm{ChV}$ that reduces the activity of proteinase, which damages lung cells. Similarly, Chan et al. [9] observed that green tea abolished the enlargement of airspace within the lung of cigarette smoke-exposed rats.

The results of the present study indicate that cigarette smoke leads to the development of airspace enlargement with many inflammatory cells in the lung tissues, both are morphometric parameters indicating emphysema. There was also an increase in the lipid peroxidation level as well as DNA damage. However, all these abnormal changes associated with smoking were restored when the rats were supplemented with the microalgae, $\mathrm{ChV}$.

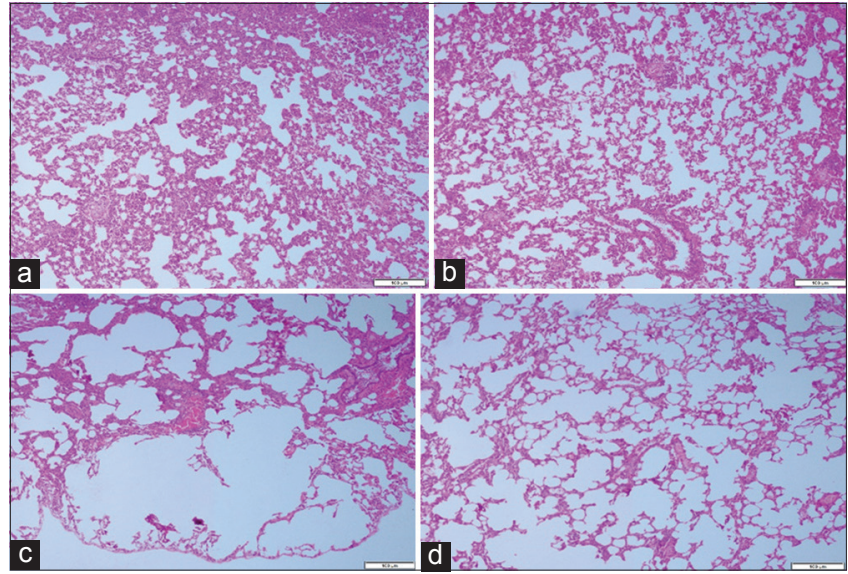

Fig. 5: Photomicrographs of lung sections showing the effect of Chlorella vulgaris ( $\mathrm{ChV}$ ) on airspace enlargement in the cigarette smoke-exposed rats (S). Control group (a), ChV group (b), S group (c), and S+ChV group (d). Scale bar $100 \mu \mathrm{m}$. H and E photomicrographs are $100 \times$ magnification

Table 1: Histopathological changes in the cigarette smoke-exposed rats and the effect of $\mathrm{ChV}$ treatment

\begin{tabular}{ll}
\hline Group (N) & Airspace enlargement \\
\hline Control (6) & 0 \\
ChV (6) & 0 \\
Smoke (6) & 6 \\
S+ChV (6) & 4
\end{tabular}

ChV: Chlorella vulgaris. Number in parentheses depicts that the total number of rats used in the experiment and airspace enlargement is reported as the number of rats that appeared to have airspace enlargement after treatment.

\section{CONCLUSION}

$\mathrm{ChV}$ has a protective role in cigarette smoke-exposed rats by reducing oxidative DNA damage, MDA levels, lung cells' inflammation, and airspace enlargement.

\section{ACKNOWLEDGMENT}

The study was funded by the special study grant sanctioned by the Faculty of Medicine, FF-2017-177 and Japan Tobacco Company. We are indebted to the staff of the Departments of Biochemistry, Pathology and Anatomy, UKM for the technical support.

\section{AUTHOR'S CONTRIBUTIONS}

YAMY, SM: Manuscript revision, experimental design, and funding body. FA, FM: Manuscript revision, interpretation of histological findings. KSZ, MKNN, FID, DGE, NDAR, NHR: Experimental design and laboratory work, collection and analysis of data, and manuscript writing.

\section{CONFLICTS OF INTEREST}

The authors declare that they have no conflicts of interest.

\section{REFERENCES}

1. Talhout R, Schulz T, Florek E, van Benthem J, Wester P, Opperhuizen A, et al. Hazardous compounds in tobacco smoke. Int J Environ Res Public Health 2011;8:613-28.

2. Lapenna D, de Gioia S, Mezzetti A, Ciofani G, Consoli A, Marzio L, et al. Cigarette smoke, ferritin, and lipid peroxidation. Am J Respir Crit Care Med 1995;151:431-5.

3. Rahman I, MacNee W. Role of oxidants/antioxidants in smokinginduced lung diseases. Free Radic Biol Med 1996;21:669-81.

4. Carnevali S, Petruzzelli S, Longoni B, Vanacore R, Barale R, Cipollini $\mathrm{M}$, et al. Cigarette smoke extract induces oxidative stress 
and apoptosis in human lung fibroblasts. Am J Physiol Lung Cell Mol Physiol 2003;284:L955-63.

5. Goldman R, Enewold L, Pellizzari E, Beach JB, Bowman ED, Krishnan SS, et al. Smoking increases carcinogenic polycyclic aromatic hydrocarbons in human lung tissue. Cancer Res 2001;61:6367-71.

6. Saetta M, Turato G, Baraldo S, Zanin A, Braccioni F, Mapp CE, et al. Goblet cell hyperplasia and epithelial inflammation in peripheral airways of smokers with both symptoms of chronic bronchitis and chronic airflow limitation. Am J Respir Crit Care Med 2000;161:1016-21.

7. Churg A, Dai J, Tai H, Xie C, Wright JL. Tumor necrosis factor- $\alpha$ is central to acute cigarette smoke-induced inflammation and connective tissue breakdown. Am J Respir Crit Care Med 2002;166:849-54.

8. The Definition of Emphysema. Report of a national heart, lung, and blood institute, division of lung diseases workshop. Am Rev Respir Dis 1985; $132: 182-5$.

9. Chan KH, Ho SP, Yeung SC, So WH, Cho CH, Koo MW, et al. Chinese green tea ameliorates lung injury in cigarette smoke-exposed rats. Respir Med 2009;103:1746-54.

10. Banerjee S, Chattopadhyay R, Ghosh A, Koley H, Panda K, Roy S, et al. Cellular and molecular mechanisms of cigarette smoke-induced lung damage and prevention by vitamin C. J Inflamm (London) 2008;5:21.

11. Koike K, Ishigami A, Sato Y, Hirai T, Yuan Y, Kobayashi E, et al. Vitamin C prevents cigarette smoke-induced pulmonary emphysema in mice and provides pulmonary restoration. Am J Respir Cell Mol Biol 2014:50:347-57.

12. Ghazali WS, Mohamed M, Sulaiman S, Aziz A, Yusof H. Tualang honey supplementation improves oxidative stress status among chronic smokers. Toxicol Environ Chem 2015;97:1017-24.

13. Riso P, Martini D, Visioli F, Martinetti A, Porrini M. Effect of broccoli intake on markers related to oxidative stress and cancer risk in healthy smokers and nonsmokers. Nutr Cancer 2009;61:232-7.

14. Muda TF, Ismail ZI, Abdullah S, Simbak N, Haque M. The Effects of honey on inflammatory cells in cigarette smoke affected lungs in rats: A preliminary study. Res J Pharm Tech 2014;7:1382-6.

15. Abdel-Rahman M, Salem FE, Bauomy AA, Khalifa MA. Amelioative effect of carob aqueous extract on water pipe smoke induced toxicity in adult male albino rats. Int J Pharm Sci 2017;9:246-53.

16. Nithya G, Mani R, Sakthisekaran D. Oral administration of thymoquinone attenuates Benzo[a]pyrene induced lung carcinogenesis in male albino mice. Int J Phar Sci 2014;7:260-3

17. Han JG, Kang GG, Kim JK, Kim SH. The present status and future of Chlorella. Food Sci Ind 2002;6:64-9.

18. Miranda MS, Sato S, Maucini-Filho J. Antioxidant activity of the microalga Chlorella vulgaris cultured on special conditions. Boll Chim Farm 2001;140:165-8.

19. Aizzat O, Yap SW, Sopiah H, Madiha MM, Hazreen M, Shailah A, et al. Modulation of oxidative stress by Chlorella vulgaris in streptozotocin (STZ) induced diabetic Sprague-Dawley rats. Adv Med Sci 2010;55:281-8.
20. Panahi Y, Tavana S, Sahebkar A, Masoudi H, Madanchi N. Impact of adjunctive therapy with Chlorellav vulgaris extract on antioxidant status, pulmonary function, and clinical symptoms of patients with obstructive pulmonary diseases. Sci Pharm 2012;80:719-30.

21. Cesar-Neto JB, Duarte PM, Sallum EA, Barbieri D, Moreno H, Nociti FH. A comparative study on the effect of nicotine administration and cigarette smoke inhalation on bone healing around titanium implants. J Periodontol 2003;74:1454-9.

22. Sulaiman S, Wan Ngah WZ, Shamaan NA, Yusof YA. Chemopreventive effect of Chlorella vulgaris on liver cancer induced rats. Int J Cancer Res 2006;2:234-41.

23. Singh NP, McCoy MT, Tice RR, Schneider EL. A simple technique for quantitation of low levels of DNA damage in individual cells. Exp Cell Res 1988;175:184-91.

24. Mateos R, Goya L, Bravo L. Determination of malondialdehyde by liquid chromatography as the 2, 4-nitrophenylhydrazone derivative: A marker for oxidative stress in cell cultures of human hepatoma HepG2. J Chromatogr B Analyt Technol Biomed Life Sci 2004;805:33-9.

25. Valavanidis A, Vlachogianni T, Fiotakis K. Tobacco smoke: Involvement of reactive oxygen species and stable free radicals in mechanisms of oxidative damage, carcinogenesis and synergistic effects with other respirable particles. Int J Environ Res Public Health 2009;6:445-62.

26. Luchese $\mathrm{C}$, Pinton S, Nogueira CW. Brain and lungs of rats are differently affected by cigarette smoke exposure: Antioxidant effect of an organoselenium compound. Pharmacol Res 2009;59:194-201.

27. Mohamed M, Sulaiman SA, Jaafar H, Sirajudeen KN. Antioxidant protective effect of honey in cigarette smoke-induced testicular damage in rats. Int J Mol Sci 2011;12:5508-21.

28. Khanna AK, Xu J, Mehra MR. Antioxidant N-acetyl cysteine reverses cigarette smoke-induced myocardial infarction by inhibiting inflammation and oxidative stress in a rat model. Lab Invest 2012;92:224-35.

29. Cosio MG, Majo J, Cosio MG. Inflammation of the airways and lung parenchyma in COPD: Role of T cells. Chest 2002;121:160S-5.

30. O'Donnell R, Breen D, Wilson S, Djukanovic R. Inflammatory cells in the airways in COPD. Thorax 2006;61:448-54.

31. MacNee W. Pathogenesis of chronic obstructive pulmonary disease. Clin Chest Med 2007;28:479-513, v.

32. Sibi G, Rabina S. Inhibition of pro-inflammatory mediators and cytokines by Chlorella vulgaris extracts. Pharmacog Res 2016;8:118-22.

33. Chalini K, Johnson M, Adaikalaraj G, Vidyarani G, Ramakrishnan P. Anti-inflammatory activity of aqueous extracts of Gracilaria. Int J Curr Pharm Res 2017;9:17-9.

34. Karale P, Karale M. An overview on plants with anti-inflammatory potential. Int J Curr Pharm Res 2017;9:1-4.

35. Al-Awaida W, Akash M, Aburubaiha Z, Talib WH, Shehadeh H. Chinese green tea (Lung Chen) consumption reduces oxidative stress, inflammation and tissues damage in smoke exposed rats. Iran J Basic Med Sci 2014;17:740-6.

36. Shapiro SD. Animal models for COPD. Chest 2000;117:223S-7. 